\title{
HUMAN INVENTORSHIP IN EUROPEAN PATENT LAW
}

\author{
EVA STANKOVÁ*
}

\begin{abstract}
This article uses the advancements in artificial intelligence as the starting point for consideration of the role of human inventorship in European patent law. It argues that human inventorship is a necessary condition for the existence of an invention and inventive step, with the result that only products of human inventorship merit European patents. It identifies failings of European authorities to reflect this adequately in their approaches to determining patentability. Finally, it recommends recognising human inventorship as an implicit patentability requirement being an aspect of the statutory requirements for an invention and inventive step and extending applicant's disclosure duties correspondingly.
\end{abstract}

\section{KEY WORDS}

Patent, Artificial intelligence, Inventorship, Invention, Inventive step

\section{INTRODUCTION}

In recent years, the imaginations of patent lawyers have been captured by the possibility of patents for inventions made by machines. The question of machine inventors has been brought to the fore by a series of patent applications in which DABUS, an artificial intelligence-driven system, was designated as the inventor of the inventions that were the subject of those applications. ${ }^{1}$ Not only was DABUS designated as the inventor, but it was also later reasserted that it indeed had devised the inventions and thus the inventions had no human inventor. ${ }^{2}$

These events have fuelled a debate about whether artificial intelligence ("AI") has reached a stage at which AI-driven systems are able to devise inventions autonomously. Some argue that the systems are not capable of any such achievements. ${ }^{3}$ Others claim that the systems are indeed

* DPhil candidate, CDT in Cyber Security and Faculty of Law, University of Oxford. This article incorporates my doctoral research which is funded by the Engineering and Physical Sciences Research Council (EPSRC). Address for Correspondence: St Cross College, 61 St Giles', Oxford OX1 3LZ. Email: eva.stankova@cybersecurity.ox.ac.uk. I am grateful to Professor Justine Pila for her comments on earlier versions of this article and to the participants at the European IP Institutes Network Innovation Society (EIPINInnovation Society) conference taking place in January 2020 for commenting on the first draft of this article. European patent applications EP 18275163 and EP 18275174 were refused by the EPO in a reasoned decision of 27 January 2020, appeal pending. In the UK, two patent applications GB1816909.4 and GB1818161.0 designating DABUS as the inventor were refused by the UK IPO's decision BL O/741/19 of 4 December 2019. On appeal, they were halted by the High Court in Stephen Thaler v The Comptroller-General [2020] EWHC 2412 (Pat), [2020] Bus. L.R. 2146. An appeal to the Court of Appeal is pending: Simmons-Simmons, "Court of Appeal to consider if AI system can be a patent inventor", available at https://www.simmonssimmons.com/en/publications/ckk2ji0621aip0954oyl31re9/court-of-appeal-to-consider-if-ai-system-can-be-apatent-inventor (last accessed 4 February 2021).

$2 \quad$ Stephen Thaler [2020] EWHC 2412 (Pat) at [5].

3 This is inferred from the non-existence of artificial general intelligence (AGI): "[B]ased on the majority view that AGI has not yet arrived current AI could neither invent nor author without human intervention." R. Hughes, "Is it time to move on from the AI inventor debate?", available at https://ipkitten.blogspot.com/2020/12/is-it- 
capable of producing patentable inventions, and that such inventions should be protected by patents without discrimination. ${ }^{4}$ The different viewpoints are driven both by divergent perceptions of law and different understandings of technology. The legal differences concern the relevance of an invention's history to its patentability and the meaning of "devising inventions"; the technical differences relate to the capabilities of AI-driven systems.

This article seeks to clarify the legal grounds of debate. More specifically, it argues that in Europe the history of an invention is relevant to its patentability, and that this becomes obvious when European patent law is read holistically and in the light of its factual assumptions and theoretical underpinnings. This article argues that in European patent law human inventorship is implicitly present and requires an invention to be devised through a human creative intervention and intellectual activity of inventive quality. Human inventorship in this sense should be recognised as an implicit requirement as part of the statutory patentability requirements that there be an "invention" and that the subject matter of the application involves an "inventive step." Although this investigation was prompted by concerns raised in relation to AI, the relevance of this analysis is not limited to the context of AI and its validity thus does not depend on the questioned capabilities of AI-driven systems to invent.

The analysis proceeds in four main stages. First, the article explains why the analysis is significant, in particular, because of developments in artificial intelligence (section II). Second, the article considers current European patent law and shows that human inventorship is both presupposed for an invention to exist and required for a legitimate grant of a European patent (section III). Third, and perhaps more controversially, the article observes that human inventorship is reflected in the statutory patentability requirements for an invention and inventive step (section IV). Fourth, the article proposes a modest reform with a view to restricting patent protection to products of human inventorship (section V). If adopted, the reform would ensure the European patent system's capacity to deal with the growing reliance on AI in the production of inventions. ${ }^{5}$

\section{AI-GENERATED PROBLEM}

The possibility that AI-driven systems are capable of inventing makes consideration of whether patent law contains a human inventorship requirement both an important and timely topic. More concretely, the question is whether the increasing AI-driven systems" "autonomy" in the process of devising inventions may preclude human beings who designed those systems, fed them with data, or deployed them, from claiming their inventorship in relation to the resulting subject matter.

time-to-move-on-from-ai-inventor.html (last accessed 31 January 2021). Or, similarly, this is inferred from the lack of systems" "initiative" to invent: "In all these examples, artificial intelligence did not take the initiative to invent. ... In that sense, artificial intelligence does not invent autonomously": P. Blok, "The Inventor's New Tool: Artificial Intelligence - How Does it Fit in the European Patent System?” (2017) 39 EIPR 69.

4 "At the other end of the spectrum, computers generate works under circumstances in which no human author or inventor can be identified": R. Abbott, "Artificial Intelligence, Big Data and Intellectual Property: Protecting Computer-Generated Works in the United Kingdom" in T. Aplin (ed.), Research Handbook on Intellectual Property and Digital Technologies (Cheltenham 2020) 324. Similarly, in S. Yanisky-Ravid and X. Liu, "When Artificial Intelligence Systems Produce Inventions: The 3A Era and an Alternative Model for Patent Law" (2018) 39 Cardozo L. Rev. 2215.

5 The issues of normative desirability of the grant of intellectual property or sui generis protection for AIgenerated objects that do not meet existing patentability criteria, including human inventorship, lie outside the scope of this article. 


\section{A. Neural Networks}

The AI technique most promising in terms of "autonomous inventing" is a neural network. ${ }^{6}$ The idea of artificial neural networks comes from psychology and dates back to 1958 when Frank Rosenblatt published his work on "perceptron", a probabilistic model for information storage and organisation in the brain. ${ }^{7}$ In recent years, neural networks have been gaining momentum due to accessibility of vast amounts of data (Big Data), availability of efficient computing hardware ${ }^{8}$ and a major methodological advancement - implementation of more layers of networks with different structures and different roles in the whole network. ${ }^{9}$

Neural networks are composed of interconnected nodes which carry a mathematical model. ${ }^{10}$ These nodes receive and process inputs from their neighbouring nodes and generate an output if activated. Their activation depends on (i) a weighted sum of all incoming inputs, (ii) a so-called activation function and (iii) an activation threshold. Advanced neural networks also incorporate a so-called backpropagation function which enables the network to send feedback backwards (to the nodes in the previous level) and compute gradients of error and then optimise the weights accordingly. ${ }^{11}$ Initially, the weights and activation thresholds can be set to random values and they adjust continually during the training. ${ }^{12}$

Mainly thanks to the lack of precise instructions for computation and the continual adjusting of weights and activation thresholds on their own, neural networks seem to be in some sense autonomous. Crucially, the expert knowledge that neural networks embody is "opaque". ${ }^{13}$ To quote Michael Wooldridge, professor of Computer Science at Oxford who works in AI for few decades, " ... at present, we have no idea how to interpret the knowledge and representations that neural networks embody." 14

Consequently, human beings who deploy neural networks in the process of problem-solving may have neither the control over the concrete form of the solutions nor the ability to grasp those solutions intellectually before they are completed. For instance, in 2020, an AI-driven system identified a highly effective antibiotic called halicin. The system learnt representations of molecules "automatically, mapp[ed] molecules into continuous vectors [...and designed...] molecular representations that are highly attuned to the desired property". ${ }^{15}$ The approach of the system was analytical (using abstracted information about molecular representation inscrutable and unavailable to human beings). This change of method allowed identifying structurally different

An accessible overview of other kinds of AI can be found in J. Drexl et al., "Technical Aspects of Artificial Intelligence: An Understanding from an Intellectual Property Law Perspective" (2019) Max Planck Institute for Innovation and Competition Research Paper No. 19-13, available at https://papers.ssrn.com/sol3/papers.cfm?abstract_id=3465577 (last accessed 12 January 2021).

7 F. Rosenblatt, The Perceptron: A Theory of Statistical Separability in Cognitive Systems (Project Para) (Cornell Aeronautical Laboratory 1958).

$8 \quad$ A. Roberts and M.J. Wooldridge, Artificial Intelligence (London 2018) 40.

$9 \quad$ M. Taddy, "The Technological Elements of Artificial Intelligence" (2018) NBER Working Paper No. 24301, available at https://www.nber.org/papers/w24301.pdf (last accessed 12 January 2021).

$10 \quad$ S.J. Russell and P. Norvig, Artificial Intelligence: A Modern Approach, 3rd ed., (Harlow 2016) 729.

11 W. Di et al., Deep Learning Essentials: Your Hands-on Guide to the Fundamentals of Deep Learning and Neural Network Modeling (Birmingham 2018) 87.

12 L. Hardesty, "Explained: Neural Networks", available at https://news.mit.edu/2017/explained-neural-networksdeep-learning-0414 (last accessed 12 January 2021).

13 M. Wooldridge, The Road to Conscious Machines (London 2020), 188.

14 Ibid.

15 J.M. Stokes et al., “A Deep Learning Approach to Antibiotic Discovery” (2020) Cell, 688, 689. 
antibiotics. ${ }^{16}$ The system was given a task to find a compound with a desired property in relation to E.coli (in European patent law terms, this was "the technical problem"), it was let to crawl chemical libraries and ranked halicin very high with respect to the desired property (in the same idiom, it offered a "technical solution") which was a result that no human being involved in the process was able to control or have prior knowledge of.

This article proceeds on the assumption that technical solutions can be produced without any human being originating those solutions in the sense of solving the problem themselves or determining the inventive features of the solution. The evolving capabilities of AI-driven systems raise important questions for patent law.

\section{B. Framing the Problem}

A high-profile policy initiative on the patentability of AI-driven systems' outputs invites formulations of new definitions dependent on the notion of AI and on (generating vs assisting) capabilities of AI-driven systems. ${ }^{17}$ The downside of such an approach is that there is no universally accepted definition of "AI" even in the AI field itself. Most definitions of AI are concerned either with thought processes and reasoning implying that the goal is to design machines that think like humans, or with behaviour aiming at machines that perform tasks that normally require intelligence when performed by humans. ${ }^{18}$ This uncertainty will naturally impede the efforts towards defining AI and its capabilities for regulatory purposes.

In contrast, there are advantages to framing the debate on the patentability of AI-driven systems' outputs by focussing on the relevant human activity. ${ }^{19}$ The answer would then primarily depend on the legal definition of human activity or human intervention that makes the resulting invention merit patent protection. If a human activity corresponding to the legal definition is found to having been involved in the process of devising a particular subject matter, then the subject matter will constitute a product of human inventorship and as such it can qualify for patent protection regardless of the nature of AI intervention in the process (provided the AI intervention does not break the chain of causation between the relevant activity and the resulting object). The article adopts this approach, explores the role of human inventors in patent law and considers what activity justifies granting patents under European patent law.

\section{ORIGIN OF AN INVENTION MATTERS}

This part argues that European (and international) patent law presupposes that an invention has a human origin. This is so, even though no statutory provision explicitly states that patents must only be granted for products of human inventorship. The current European legislative framework is

\section{Ibid.}

17 World Intellectual Property Organization, "Revised Issues Paper on Intellectual Property Policy and Artificial Intelligence", available at https://www.wipo.int/meetings/en/doc_details.jsp?doc_id=499504 (last accessed 19 March 2021) [15] (i).

18 Russell and Norvig, Artificial intelligence, 1-2.

19 This is recommended also by Shemtov, "[a]n approach that is both theoretically sound as well as practically workable should focus on the respective contributions of the various persons in the chain of creation": N. Shemtov, "A Study on Inventorship in Inventions Involving AI Activity", available at http://documents.epo.org/projects/babylon/eponet.nsf/0/3918F57B010A3540C125841900280653/\$File/Conce pt_of_Inventorship_in_Inventions_involving_AI_Activity_en.pdf (last accessed 26 October 2020). 
founded on factual assumptions about inventions and inventing which stem from contemporary experience of how technical solutions come to being.

\section{A. The Role of Inventors}

Patents as proprietary rights in intangible objects "emerged from the very tangible world of artisanship and crafts" 20 and hence the first inventors were artisans and craftsmen. The first patent statute which was enacted in Venice derived inventor's rights from "the very fact of his invention" 21 rather than from a privilege granted by a state. Individual rebellions against Renaissance guilds underscored the role of individual inventors and their ingenuity, e.g. a patent for the architect Brunelleschi was justified by "his own ingenuity and invention". ${ }^{22}$

In Elizabethan England patents also served to attract the importation of new technologies through welcoming their carriers and embodiments, i.e. foreign craftsmen, and artisans. ${ }^{23}$ Following public objections to royal prerogatives, the Statute of Monopolies 1623 prohibited them with few exceptions, including patents for "the true and first inventor". ${ }^{24}$ In Edgeberry $v$ Stephens this piece of legislation was interpreted as encouraging the inflow of inventions "whether learned and acquired by study or travel". ${ }^{25}$

On the other side of the Atlantic, in 1788, one of the federalists, James Madison advocated that Congress be given the power

to promote the progress of science and useful arts, by securing, for a limited time, to authors and inventors, the exclusive right to their respective writings and discoveries.' ... The copyright of authors has been solemnly adjudged, in Great Britain, to be a right of common law. The right to useful inventions seems with equal reason to belong to the inventors. ${ }^{26}$

The US Patent Act 1836 expressly referred to labour and desert policy when justifying the duration of patent rights which it was said ought to secure "for inventors the fruits of their inventive labors". 27

By the time of the drafting of the first international patent law instrument, the Paris Convention (adopted in 1883), the common understanding was that only human beings were capable of coming up with solutions to technical problems or, put in other words, to invent. ${ }^{28}$ This was reflected in Article 4ter of the Paris Convention which article guarantees a moral right of an

20 J. Kostylo, "Commentary on the Venetian Statute on Industrial Brevets (1474)" in L. Bently and M. Kretschmer (eds.), Primary Sources on Copyright (1450-1900) (2008), available at www.copyrighthistory.org (last accessed 12 January 2021).

21 Ibid.

22 P.O. Long, "Invention, Authorship, "Intellectual Property" and the Origin of patents: Notes Toward a Conceptual History" (1991) 32 Technology and Culture 846, 881.

23 C. MacLeod, Inventing the Industrial Revolution (Cambridge 2009) 11.

24 Statute of Monopolies 1623. Quoted in Kostylo, "Commentary".

25 Edgeberry $v$ Stephens (1693) 90 E.R. 1162 (K.B.).

26 J. Madison, "Federalist No. 43", available at https://guides.loc.gov/federalist-papers/text-41-50\#s-lg-boxwrapper-25493407 (last accessed 21 March 2021).

27 A. Mossoff, "Who Cares What Thomas Jefferson Thought about Patents - Reevaluating the Patent Privilege in Historical Context” (2007) 92 Cornell L. Rev. 953, 1006.

28 Encyclopaedias list only human beings and no other intelligent entities as inventors. For instance, B. Duignan, "Inventors and Inventions of the Industrial Revolution", available at https:/www.britannica.com/list/inventorsand-inventions-of-the-industrial-revolution (last accessed 12 January 2021). 
inventor to be named as such in the patent. ${ }^{29}$ In intellectual property law, moral rights are noneconomic rights whose objective is to protect the dignity and personality of authors and inventors. As such they are associated with human beings only and hence the assumption embodied in that provision was that the inventor is a human being. Recognising and providing for the moral right of the inventor caused no noteworthy controversies among the drafters of the Paris Convention. ${ }^{30}$

\section{B. $\quad$ The Right to Be Named as the Inventor}

Under the European Patent Convention 2000 ("EPC"), the inventor has the right, vis-à-vis the applicant for or proprietor of a European patent, to be mentioned as the inventor before the European Patent Office ("EPO"). ${ }^{31}$ This provision gives effect to the inventor's moral right. ${ }^{32}$ Correspondingly, Article 81 EPC requires the applicant to designate the inventor and "if the applicant is not the inventor or is not the sole inventor, the designation shall contain a statement indicating the origin of the right to the European patent" ${ }^{33}$, namely the way the title was transferred to the applicant. ${ }^{34}$ Pursuant to Article 60 EPC, the right to the European patent originally belongs to the inventor and through them their successor in title or employer.

The EPO does not verify the identity of the inventor designated in the patent application, but it notifies the designated inventor where the applicant is a different person. ${ }^{35}$ However, the EPO checks that the formal requirements of the patent application have been complied with, ${ }^{36}$ including whether the inventor was designated in a request for grant of a European patent where the applicant is the sole inventor, ${ }^{37}$ or whether the inventor was designated in a separate document where the applicant is not the inventor or the sole inventor. ${ }^{38}$ In case these formal requirements are not met, the patent application shall be refused under Article 90(5) EPC.

The European patent applications which designated the AI-driven system, DABUS, as the inventor, met just this fate. They were refused by the EPO on the ground that they did not designate

29 Paris Convention for the Protection of Industrial Property of March 1883 (latest version, Stockholm 1967, with 1979 amendments), Article 4ter: "The inventor shall have the right to be mentioned as such in the patent" read in conjunction with G. Bodenhausen, WIPO Guide to the Application of the Paris Convention (Geneva 1968), 64 wherein it is explained that the right under Article 4ter is "commonly called a moral right".

30 S. Ricketson, The Paris Convention for the Protection of Industrial Property A Commentary (Oxford 2015), 389. There are no indications that the drafters would have regarded inventors as including any other entities than human beings. Human inventorship was not debated as a potential condition for patent validity because the Paris Convention did not aim to harmonise substantive patent law. See ibid., 443 et seq. In contrast, the Agreement on Trade-Related Aspects of Intellectual Property Rights ("TRIPS") sets out substantive patentability criteria such as invention or inventive step. However, it does not define those notions and they are left to be defined "in good faith" by the Members: C. Correa, Trade Related Aspects of Intellectual Property Rights: A Commentary on the TRIPS Agreement, 2nd ed., (Oxford 2020), Ch. 9.

31 EPC, Article 62.

32 P. Hess, "EPC 2000, Art 62" in R.J. Hacon and J. Pagenberg (eds.), Concise European patent law, 2nd ed., (Alphen an den Rijn 2008) 67.

33 EPC, Article 81 and Implementing Regulations to the EPC, Rule 19(1).

34 Travaux préparatoires to the EPC 1973, Minutes of the Munich Diplomatic Conference for the Setting up of a European System for the Grant of Patents, M/PR/I, para. 265, available at https://www.epo.org/lawpractice/legal-texts/epc/archive/epc-1973/traveaux.html (last accessed 29 March 2021).

35 Implementing Regs., Rule 19(3): "If the applicant is not the inventor or is not the sole inventor, the European Patent Office shall communicate to the designated inventor the information in the document designating him ...".

EPC, Articles 78 and 90.

Implementing Regs., Rule 41.

Ibid., Rule 19. 
the inventor. ${ }^{39}$ From this verdict it follows that an AI-driven system cannot serve as a designated inventor in the patent grant proceedings before the EPO presumably because the EPC system presupposes that each invention has an individualised human inventor. It also makes clear that the failure to designate a human being as the inventor raises a formal obstacle to the substantive examination of the patent application and thus grant of a European patent. Thereby, at least formally and implicitly, it is required that the invention the subject of a patent application has a human inventor.

The trouble is that in practice, in the event of a de facto absence of human inventor, the provision of Article $62 \mathrm{EPC}$ securing the right of the inventor to be named becomes irrelevant. Moreover, it seems that the above-mentioned formal obstacle to the grant of a European patent can be (pragmatically rather than legally) overcome by merely naming a natural person as the inventor in the European patent application since the identity of the inventor is not verified by the EPO. The possibility of such a manoeuvre exposes a shortcoming with the examination system as set out by the EPC and its Implementing Regulations. Consequently, subject matter that have a human inventor on paper only (and do not in fact have one) could proceed to a substantive examination as if they were products of human inventorship.

\section{The Right to a Patent}

Even if the problem of missing human inventor may seem of little practical consequence in the patent grant proceedings before the EPO (provided applicants put a name of a human being forward as a matter of formality), it becomes more intriguing when it comes to entitlement to a European patent.

To reiterate, pursuant to Article 60(1) EPC, the right to a European patent shall belong to the inventor or his successor in title. This right comprises the "inventor's personal right [that has as its object] the relationship of the inventor to their creation and a personal position and acknowledgment resulting therefrom" 40 on one hand and the material right to grant of a patent derived therefrom on the other hand. ${ }^{41}$ The right to a European patent is an expression of a "fundamental principle of almost all European patent systems" 42 and arises upon completion of the invention. ${ }^{43}$ Thus, the right to patent exists by virtue of the act of invention and it precedes the grant of the patent by an act of state administration.

The EPC does not specify what one must do to gain the status of inventor and thus become originally entitled to the European patent. The individual inventorship question as well as any disputes related to the entitlement are to be brought before national courts of the EPC Contracting States. ${ }^{44}$ These courts apply the respective national patent laws that define the inventor as a human

\footnotetext{
39 EPO decision of 27 January 2020 on patent applications EP 18275163 and on EP 18275 174, under appeal.

40 K.J. Melullis, "Patentfähige Erfindungen" in G. Benkard (ed.), Europäisches Patentübereinkommen (Munich 2002) 301.

41 Ibid.

42 Travaux préparatoires to the EPC 1973, Texts Drawn Up by the Drafting Committee of Main Committee I at the Meeting on 12 September 1973, M/74/I/R 1, available at https://www.epo.org/law-practice/legaltexts/epc/archive/epc-1973/traveaux.html (last accessed 29 March 2021).

43 M. Haedicke, "\$3 Ownership A. Inventor and inventor right” in M. Haedicke and H. Timmann (eds.) Patent Law: A Handbook on European and German Patent Law (Baden 2014) 244.

44 EPC, Article 61 and the Protocol on Jurisdiction and the Recognition of Decisions in respect of the Right to the Grant of a European Patent (Protocol on Recognition), Article 1. See further Patents Act 1977, s. 7(2), Patentgesetz of 16.12.1980 (BGB1. 1981 I S. 1) (“German Patent Act") §6, the Code de la propriété intellectuelle, Article L611-6.
} 
being who actually devised, ${ }^{45}$ made,${ }^{46}$ or originated ${ }^{47}$ an invention.

In UK law, for example, an inventor is defined as the actual deviser of the invention. ${ }^{48}$ The actual deviser of the invention is understood to be the "natural person" 49 who "came up with the inventive concept" 50 or who "was responsible for the inventive concept". ${ }^{51}$ More specifically, to merit the status of an inventor, one must originate the inventive idea or contribute information necessary to make the idea patentable and enable the invention to work. ${ }^{52}$ Entrepreneurial or managerial contributions are unlikely to be seen as inventive contributions. ${ }^{53}$ In general, UK law requires a natural person to develop an inventive idea sufficiently to enable its use by others to solve a technical problem. Hence, human inventorship entails the origination and development of the inventive concept embodied in the invention.

Before the EPO, the person deemed entitled to exercise the right to a European patent is the applicant. ${ }^{54}$ For this provision as well as for the EPO's lack of competence to examine the entitlement, a European patent may happen to be granted to a person who is not entitled to it, i.e. in breach of Article 60(1) EPC. The remedy is that, in the post-grant phase, the European patent can be revoked by national courts of the EPC Contracting States (with the effect ex tunc and for the territory of the respective Contracting States) on the ground that its proprietor is not entitled to it $^{55}$ ("lack of entitlement").

Taking this together, a European patent is legitimately granted only if it is granted to the human inventor of the underlying invention the subject of the patent application or their successor in title. Should a European patent be granted despite its proprietor's lack of entitlement, such a patent is open to a revocation attack. If eventually revoked, it is then treated as if it had never been granted in the first place.

As the revocation on the ground of lack of entitlement is governed by national laws, the revocation proceedings in the EPC Contracting States differ to some extent. For instance, in the UK, they can only be initiated by a person who was found by the court or the comptroller to be entitled to be granted that patent. ${ }^{56}$ In Germany, application for the revocation can be brought only by an interested party, and, in case of usurpation only by the injured party. ${ }^{57}$ In France only the

$45 \quad$ Patents Act 1977, s. 7(3).

46 A person gains the status of an inventor when he "makes an invention, so he himself acquires knowledge how to solve a particular technical problem with certain technical means ... and he discloses his knowledge ... as an instruction that can be used for technical implementation": Steuervorrichtung, Decision of 18 May 2010 - X ZR 79/07 (GRUR 2010, 817) at [28].

47 "The law attributes, ... the ownership to the invention to a person who originated it": P. Sirinelli, Code de la propriété intellectuelle, 19th ed. (Paris 2019), 572.

$48 \quad$ Patents Act 1977, s. 7(3).

49 Yeda Research $v$ Rhone-Poulenc Rorer International Holdings Inc. [2007] UKHL 43, [2008] 1 All E.R. 425 at [20].

50 Ibid., Lord Hoffman referred to Laddie J in University of Southampton's Applications [2004] EWHC 2107 (Pat), [2005] R.P.C. 11, [39].

$51 \quad$ Henry Brothers v MOD [1997] R.P.C. 693, 706 (Ch.).

52 IDA v The University of Southampton [2006] EWCA Civ 145, [2006] R.P.C. 21, at [39].

53 L. Bently et al., Intellectual Property Law, 5th ed. (Oxford 2018) 627.

$54 \quad$ EPC, Article 60(3).

55 EPC, Article 138(1)(e) (Article 138 Revocation of European patents / Artikel 138 Nichtigkeit europäischer Patente / Article 138 Nullité des brevets européens).

56 Patents Act 1977, s. 72(1)(b) in conjunction with s. 72(2).

57 German Patent Act, Nullity Proceedings and Compulsory Licence Proceedings (Nichtigkeits- und Zwangslizenzverfahren) §81(3). 
inventor or their successor in title can file the application for the revocation on the ground of lack of entitlement. ${ }^{58}$

This excursion to national patent laws, albeit brief, shows that the initiation of national revocation proceedings on the ground of lack of entitlement under Article 138(1)(e) EPC lies largely in the hands of the inventor or their successor in title. This is reinforced by the fact that neither the EPO nor national patent authorities (at least in the UK and Germany) ${ }^{59}$ check the entitlement ex officio. As observed by Marcus Smith J. in relation to the UK DABUS patent application, an applicant's statements concerning the identity of an inventor or succession in title cannot possibly be audited by the national patent authority in each case. ${ }^{60}$ Consequently, in practice, in the de facto absence of a human inventor, there seems to be no legal basis for revocation of a European patent due to lack of entitlement.

In sum, the EPC system presupposes the existence of an individualised human inventor and reflects this normatively, both in the inventor's designation and entitlement requirements under Articles 62, 81 and 60(1) EPC. Reading this in conjunction with national definitions of an inventor, a human being devising an invention is assumed to be a precondition for the existence of an invention as well as for the legitimate grant of a European patent. Hence, the human origin and history of an invention is of legal significance under the EPC system. However, as the existence of human inventors is taken for granted without verifying the inventors' status or legitimacy of applicants' entitlement declarations, the EPC system fails to operate flawlessly in no human inventor scenario.

\section{Patentability}

Leaving the realm of individual inventors' rights and their relative claims, this article argues that (general) human inventorship is a necessary condition for the patentability of any subject matter. As shown above, the existence of an individualised human inventor and their inventorship are presupposed by the EPC (and the Paris Convention).

The presumption that each invention has an individualised human inventor subsumes a more general belief that an invention originates from a human being. More specifically, in the UK, German and French laws, the inventor is defined as someone who actually devised, made, or originated respectively an invention. Rephrasing this in a subject matter-centred fashion, an invention can be understood as something actually having been devised or made by an inventor, ${ }^{61}$ i.e. something owing its existence to a certain kind of human activity or intervention.

The proposition that the existence of an invention is predicated on human activity or intervention has been made on a number of other occasions. For instance, Professor Pila recognises "origination in an act of human creation (requiring a certain talent or capacity)" as one of the common definitional elements of intellectual property subject matter. ${ }^{62}$ Elsewhere, Professor

58 Cour de cassation, Decision of 14 February 2012, $\mathrm{n}^{\circ} 11-14.288$.

59 Intellectual Property Office, "Manual of Patent Practice" (2016) at [13.12]. The accuracy of the inventor's designation is not verified by the German Patent and Trade Mark Office, German Patent Act, $\$ 37$.

60 Stephen Thaler [2020] EWHC 2412 (Pat) at [29].

61 An argument along these lines was made by Marcus Smith J in ibid., at [45].

62 J. Pila, The Subject Matter of Intellectual Property (Oxford 2017), 9. The monograph is focused on European and UK law. 
Sherman conceptualises invention as "a product of a process in which a human agent (or inventor) exercises their inventive skills to build on, modify, or adapt preexisting natural materials". ${ }^{63}$

Accounts along these lines are also found in commentaries from civil law jurisdictions. The former German Supreme Court judge Melullis describes the importance of human activity for the concept of invention as follows: "[a]s a result of an intellectual activity by individualised natural persons the invention is necessarily connected with the inventor; an invention without inventor is not thinkable". ${ }^{64}$ Professor Haedicke writes that "the prerequisite for every invention ... is an intellectual process of invention". ${ }^{65}$

The language of origination and intellectual process brings copyright to mind. Drawing a parallel between copyright and patents could be helpful to demonstrate the relationship between human authoring (or inventing) and copyright subsistence (or patentability) of a resulting subject matter. Indeed, Professor Ginsburg argues that "originality is synonymous with authorship"66 while the conceptions of originality (and so the contribution required to gain the status of author) differ jurisdiction by jurisdiction. ${ }^{67}$ At a more abstract level though, originality is an internationally recognised copyright subsistence criterion. ${ }^{68}$ Hence, in principle, if a subject matter does not have any human author and thus lacks human authorship, not only there is no one entitled to copyright, but also, and more fundamentally, such subject matter is not eligible for copyright protection as an authorial work. ${ }^{69}$

It is curious that the connection between human inventorship (or human origin) and patentability of a subject matter does not attract much attention in modern scholarship. ${ }^{70}$ Yet, scrutinising the patentability of subject matter that have not in fact been devised by a human inventor (but that might easily be disguised as having been so devised) is important for preserving the coherence and integrity of the modern patent system.

If subject matter that lacks human inventors could enjoy patent protection, this would be at odds with the idea of patents as rewards and incentives for human beings who devise inventions and disclose them. Granting patents for products of human inventorship as well as subject matter

63 B. Sherman, "What Does It Mean to Invent Nature?” (2015) 5 U.C. Irvine L.R., 1193, 1203. The article analyses US and Australian doctrine.

64 Melullis, "Patentfähige Erfindungen”, 310.

65 M. Haedicke, “ $\$ 3$ Ownership A. Inventor and Inventor Right” in M. Haedicke and H. Timmann (eds.), Handbuch des Patentrechts (Munich 2012), at [1] and [5].

66 J.C. Ginsburg, "The Concept of Authorship in Comparative Copyright Law” (2003) 52 DePaul L. Rev. 1063, 1078.

67 Ibid.

68 Originality or "intellectual creation" as provided in the Berne Convention for the Protection of Literary and Artistic Works (Paris Act of 24 July 1971), as amended on 28 September 1979 (“Berne”), Article 2(1). "“[I]ntellectual creation' is implicit in the conception of a literary or artistic work": S. Ricketson and J.C. Ginsburg, International Copyright and Neighbouring Rights: The Berne Convention and Beyond, vol. I, 2nd ed., (Oxford 2006) 402.

69 In copyright law, this is more straightforward because no act of state administration is required for copyright to subsist. Berne, Article 5(2). In contrast to patent law, the UK copyright law contains a legal fiction of an author for computer-generated works in the Copyright, Designs and Patents Act 1988, s. 9(3). As this provision constitutes a deviation from the general principle of authorship requiring a human creator of authorial works and is strictly limited to UK copyright, it is not discussed here at any length. For further details, see Bently et al., Intellectual Property Law, 117-18.

70 "[M]odern patent lawyers so rarely ask the question: what is the invention? ... Although the requirements for patentability do not include a discrete requirement that applicants be able to show that they have created an invention, it is clear that the invention occupies a pivotal place in patent law": A. Pottage and B. Sherman, Figures of Invention: A History of Modern Patent Law (Oxford 2010) 3. 
lacking a human inventor would eventually render the patent system incoherent and its outcomes inconsistent because it would mean treating fundamentally dissimilar objects equally. It would also represent significant legal reform by means of administrative and judicial decision-making rather than democratic legislative process.

\section{REFLECTIONS OF HUMAN INVENTORSHIP IN THE STATUTORY PATENTABILITY REQUIREMENTS}

Pursuant to Article 52(1) EPC, "European patents shall be granted for any inventions, in all fields of technology, provided they are new, involve an inventive step and are susceptible of industrial application". Out of these statutory patentability criteria, this section focuses on the requirements for an invention and inventive step. At first glance, the requirement for an invention appears to be the closest reflection of human inventorship in positive law as the invention represents the inventor's contribution to the state of the art. ${ }^{71}$ Equally, the requirement for an inventive step aims at identifying the inventor's intellectual contribution as it is suggested by its anthropomorphic phrasing. ${ }^{72}$

Further, this section analyses the approaches to the application of these requirements adopted by the EPO and courts in the UK, Germany, and France. These jurisdictions emerge from different legal traditions while adhering to the same patentability requirements harmonised by the EPC in 1973. The analysis indicates that despite these jurisdictions sharing the overarching legal basis and following the decision-making practice of the EPO, ${ }^{73}$ they take marginally different approaches to the application of the requirements. In each of these approaches, however, the concept of "invention" is reduced to designate merely a technical feature (the EPO, France), belonging to a technical field (Germany) or technical contribution (the UK). As a result, there is a danger that the tests overlook the human component of invention, that is, that there is subject matter that falls within a technical field or has a technical feature, but which does not constitute "an invention" because of lack of the relevant human origin.

In the assessment of the requirement for an inventive step, the notion of "obviousness" overshadowed human intellectual aspects of the inventive step which are emphasised in the EPC drafting documents, recognised in Actavis $v$ ICOS (the UK) and found in a typology of inventive activities (Germany, France). These approaches can lead to finding non-obviousness in inventions which may not involve the relevant human intellectual activity.

71 For instance, in German law (until the reform in 1968) there were no separate requirements for an invention and inventive activity. Rather, the achievement or the contribution to the art was understood as the main patentability criterion. See R. Nack, "Inventions and their amenability to patent protection" in M. Haedicke and H. Timmann (eds.) Patent Law: A Handbook on European and German Patent Law (Baden 2014) at [24]. Or, '[t]he definition of an invention as being a contribution to the art ...'. See Factor-9/JOHN HOPKINS, T 1329/04 of 28 June 2005, EP:BA:2005:T132904.20050628, at [12].

72 An invention is required to involve an "inventive step", or "inventive activity" pursuant to EPC, Article 56. Similarly, Aplin chooses novelty and inventiveness when giving an account of creativity in patent law. T. Aplin, "Creativity and the Law" in L. Martin and N. Wilson (eds.), The Palgrave Handbook of Creativity at Work (Basingstoke 2018). Put in other words, "creativity reappeared in the form of the requirements of originality and non-obviousness, in which applicants had to show, in effect, that their respective works were creative." B. Sherman and L. Bently, The Making of Modern Intellectual Property Law: The British Experience, 1760-1911 (Cambridge 1999), 200.

73 The settled jurisprudence of the EPO on the interpretation of the EPC should normally be followed. Actavis Group PTC EHF v ICOS Corporation [2019] UKSC 15, [2020] 1 All E.R. 213, at [56]. 


\section{A. The Invention Requirement}

The criterion of an "invention" is a self-standing patentability requirement under the $\mathrm{EPC}^{74}$ and any subject matter must first qualify for an invention. The rare instance where the nature of an invention has been more comprehensively considered by the most authoritative interpreter, the Enlarged Board of Appeal of the European Patent Office ("EBA"), ${ }^{75}$ is Tomatoes/State of Israel. ${ }^{76}$ The EBA was asked, inter alia, whether a method of crossing and selecting plants escapes the exclusion of Article 53(b) EPC of "essentially biological processes," by virtue of containing an additional feature of a technical nature. ${ }^{77}$

In her response, the EBA made a general statement that the "essence of invention" is "human intervention in a process in order to bring about a desired result". ${ }^{78}$ The EBA thus interpreted the concept of "invention" as requiring "human intervention"79 or an intentional abstention therefrom. ${ }^{80}$ Most recently, this approach was embraced in the EBA's decision on patentability of a simulation method (i.e. outside the biotechnology context). ${ }^{81}$ The EBA also added that the technicality of the invention "implies that an object is created, or a process is run with some purpose based on human creativity". 82

These decisions suggest that a human intervention is required for an invention to be created. ${ }^{83}$ In Tomatoes, the EBA required the intervention to cause a durable and permanent change

74 Estimating Sales Activity/DUNS LICENSING ASSOCIATES, T 0154/04 of 15 November 2006, EP:BA:2006:T015404.20061115, at [5].

75 The EBA is a quasi-judicial body of the EPO. It is tasked with ensuring a uniform application of the EPC, deciding points of law of fundamental importance and with a limited judicial review of decisions of the Boards of Appeal. EPC, Articles 112, 112a.

76 Tomatoes/State of Israel, G 0001/08 of 9 December 2010, EP:BA:2010:G000108.20101209.

77 Even though the referral concerned interpretation of EPC, Article 53(b) primarily, this question hints at the category of "as such" non-inventions under Article 52(2) EPC and their saving through a step of technical nature. Thus, the EBA started answering the question by defining what technicity and invention under Article 52(1) EPC mean.

78 Tomatoes, at [6.4.2.3] and the same at [6.4.2.1]. The same also Broccoli/PLANT BIOSCIENCE, G 0002/07 of 9 December 2010, EP:BA:2010:G000207.20101209 at [6.4.2.1].

79 Ibid., at [6.4.2.1]. It may be objected that the EBA contrasts "human" to "natural/biological intervention" in this decision. Rather it contrasts the effects of a human intervention and natural "intervention" of sexual crossing on the resulting subject matter. The EBA distinguishes between technical steps that (i) merely enhance or assist the biological processes and those that (ii) change the result. In principle, inventions in all technical fields secure their technical character through human intervention in the nature. This applies to inventions in computer science (e.g. utilising electricity), chemistry (e.g. utilising properties of various materials), mechanics (e.g. utilising natural laws of motion), etc.

$80 \quad$ Ibid., at [6.4.2.3].

81 Simulation Method, G 0001/19 of 10 March 2021, EP:BA:2021:G000119.20210310 at [75].

82 Ibid, at [46] and [47].

83 Though both decisions imply intentionality or purpose, the EBA does not specify this further. Nonetheless, it follows that in Tomatoes and Simulation method inventions are understood as creations, i.e. reproducible results of a process involving human intervention. Some scholarship mentions "accidental inventions", i.e. "accidental discoveries, [which] at least at the moment of the serendipitous event, lack conception." S.B. Seymore, "Serendipity" (2009) 88 N.C.L. Rev. 185, 191. However, neither the accidental event of discovering a substance nor the discovered substance amount to an invention in the sense of Tomatoes. The "serendipper" can turn a discovery into an invention by acquiring knowledge about how to re-create it, how to incorporate it into a process with industrial application, etc.: see more in the following section. 
in the resulting subject matter (such as a genetic change in a living product ${ }^{84}$ ) and that the intervention was repeatable. ${ }^{85}$ The decisions thus acknowledge the necessity of a causal connection between a human being who intervenes in the world with a view to achieving a desired result and a materialised result. ${ }^{86}$ Such causally determinative human intervention is referred to as human "creative" intervention further on.

\section{The invention vs discovery}

An invention (understood as a creation) is often juxtaposed to an unpatentable discovery. According to a Comparative Study of Substantive Law (the "Comparative Study") which influenced the drafting of the EPC 1973 and its accompanying Community Patent Convention, "[a]s a general rule, a patent can only protect an invention (a creation) and not a discovery, i.e. the simple taking note of a pre-existant [sic] reality." 87

The French scholarship captures the distinction as follows: "[i]n the invention itself, the activity of a human is productive, in the discovery, [the activity] is, so to say, receiving". ${ }^{88}$ This is affirmed by another definition of an invention founded on the underlying activity and thus defined as "every action or endeavour of a human being to shape and utilise the nature and the matter". ${ }^{89}$

The German account of the distinction hinges on the relevant activity as well: "'[i]nvention' and 'discovery' each describe the product of a particular human activity, that of discovering and that of inventing. These two forms [discovery and invention], therefore, simply mean 'what is discovered' and 'what is invented' and primarily indicate the nature of activity that leads to this acquisition of knowledge." 90

In general, a discovery involves finding and disclosing information about the natural world, including describing properties of a pre-existing matter. ${ }^{91}$ A transformation of a discovery into an invention requires "an act of invention or human ingenuity". ${ }^{92}$ For instance, a discovery that is implemented in a reproducible process may constitute an invention whereas a mere reformulation

84 Tomatoes, at [6.4.2.3]. This comes from the part of the decision where the EBA interprets the "essentially biological process" exception to patentability. In sum, (i) if there is a technical step in a process then the process is an invention; (ii) if the technical step in a process which is based on the sexual crossing of plants and on subsequent selection only serves to perform the process steps of the breeding process then such a process is excluded; (ii) if, however, the technical step within such a process determines the result to some extent then the process is outside the exception and bounces back to constitute an invention.

85 Ibid., at [6.4.2.1].

86 To put it differently, an invention "must represent an objectively determinable and causally determined result of human intervention in the physical world that is also repeateable": J. Pila and P. Torremans, European Intellectual Property Law, 2nd ed., (Oxford 2019) 157.

87 R. Gajac, "Comparative Study of Substantive Law in Force in the Countries Represented on the Committee of Experts on Patents" EXP/Brev (53) 18 as reproduced in J. Pila, The Requirement for an Invention in Patent Law (Oxford 2010), 138. The Comparative Study was prepared in 1953 under the auspices of the Council of Europe.

88 M. Vivant and J.M. Brugière, "Réinventer l'invention?" (2003) 8 P.I. 286 quoting P. Roubier, Le droit de la propriété industrielle, vol. 2, (Paris 1954), 90.

89 J. Passa, Droit de la propriété industrielle, 2nd ed. (Montchrestien 2013), 74 quoting P. Mathély, "Le nouveau régime des brevets d'invention" (1969) Ann.prop.ind. 1, spec. 9.

90 However, further in the text Nack does not connect this activity-based distinction with patentability of a subject matter. Nack, "Inventions", at [149].

91 S. Thorley et al. Terrell on the Law of Patents 15th ed. (London 2000) at [2-69] (not included in the 19th ed.) S. Sterckx and J. Cockbain, Exclusions from Patentability: How Far Has the European Patent Office Eroded Boundaries (Cambridge 2012), 115.

92 Sterckx and Cockbain, Exclusions, 133. 
of a discovery in the form of a technical teaching does not render it patentable. ${ }^{93}$ Exceptionally, the required human intervention is specified, e.g. in the case of biotechnological inventions the making of which requires an act of isolation of biological material from its natural environment, or its synthetic production. ${ }^{94}$

\section{Teleological interpretation and historic reasons for a human intervention}

The policy documents which accompanied the amendments of the EPC in 2000 further corroborate the importance of creations under the EPC framework. Prominently, they state that " $\mathrm{t}] \mathrm{he}$ new wording of Article 52(1) EPC plainly expresses that patent protection is reserved for creations in the technical field." 95 This equates inventions with creations. According to the Oxford English Dictionary, the ordinary meanings of "creation" are (i) "something created by divine or natural agency" and (ii) "an original production of human intelligence, power, skill, or art; esp. a work of imagination". ${ }^{96}$ Since modern patent law was designed for human inventors and their inventions, as shown in Section III, creations by God and nature can be filtered out. Hence, the creations in all technical fields mean products of human intelligence, skill, etc. in all technical fields. The Comparative Study further emphasises the role of human origin of an invention: "one can infer from what has been said the rule that the author of a patentable invention must have been presented with a problem and have indicated a solution to it". ${ }^{97}$

In the landmark decision Rote Taube (pre-dating the EPC 1973), the German Supreme Court affirmed that subject matter should not be treated as non-inventions when they involve a methodical utilisation of controllable natural forces and phenomena (not only in the fields of physics, chemistry but also biology) to achieve a causal, perceivable result. ${ }^{98}$ The requirement of repeatability of the method and reproducibility of the result was adopted by the EBA in Tomatoes/State of Israel to form part of the EBA's interpretation of the notion of "invention".

As creations from all technical fields must be treated equally, ${ }^{99}$ an identical definition of an invention should apply to subject matter coming from any field of technology. Therefore, the authorities should apply the same standard and have the same task of ascertaining whether a certain subject matter is an invention, including the aspect of its origin. This means asking whether the subject matter constitutes a product of human creative intervention, and thus is attributable to a human being.

\section{Application of the invention requirement}

In practice, when the EPO examines the requirement for an invention, the scrutiny is limited to finding so-called "technical character." The requirement of technical character emerged from the case law on the application of Article 52(2) EPC. This provision contains a non-exhaustive list of

93 Melullis, "Patentfähige Erfindungen", 346.

94 Directive (EU) 98/44/EC (OJ 1998 L 213 p. 13), Article 3.

95 Special edition 4/2007 Revision of the European Patent Convention (EPC 2000) Synoptic presentation EPC 1973/2000 - Part I: The Articles Part II Chapter I Article 52 EPC.

96 "Oxford English Dictionary", available at https://www.oed.com/ (last accessed 27 April 2021).

97 Gajac, "Comparative Study", 3-7 as referred to in Pila, The Requirement, 139.

98 Rote Taube, Decision of 27 March 1969, X ZB 15/67 (IIC 1970, 136) 138. Also see J. Straus, "Biotechnologische Erfindungen - ihr Schutz und seine Grenzen" (1992) GRUR 252, 258.

99 TRIPS, Article 27(1) prohibits discrimination on the grounds of the field of technology. 
categories of subject matter that are excluded from patentability as non-inventions. ${ }^{100}$ This list may also be read as a "negative definition of the notion of invention"101 and it "covers subjects whose common feature is a substantial lack of technical character". ${ }^{102}$

However, where a subject matter merely relates to excluded subject matter it can still qualify for protection as an invention provided its technical character is demonstrated. ${ }^{103}$ It is through this interpretative route (via the negative definition of an invention) that the requirement for an invention became transformed into a "requirement of technicality"104 (or technicity). In practice, the technical character can be demonstrated through a subject matter (i) involving technical means, (ii) producing a technical result or (iii) involving a technical field of human activity. ${ }^{105}$ When it comes to computer-implemented methods, the EPO looks for "further technical effect"106 going beyond the normal interaction of the features.

In the UK practice, no positive definition of an invention is recognised by courts. ${ }^{107}$ In the view of Lord Hoffmann, the novelty, inventive step, and industrial applicability criteria, when taken in conjunction, probably amount to an invention, unless the grant of a patent for it is excluded. ${ }^{108}$ A subject matter is considered not to be excluded if the contribution contained therein is "actually technical in nature". ${ }^{109}$ In the case of computer-implemented inventions, the required technicity is established if the subject matter produces a relevant technical effect which depends on the facts of each case. ${ }^{110}$

For instance, in HTC Europe $v$ Apple, it was found that "a method of dividing up the screen of such a device into views and configuring each view as a multi-touch view or a single-touch view using flags with a specific functionality" makes a technical contribution, its embodiment in software notwithstanding, as it "presents a new and improved interface to application programmers, ... and makes it easier for them to write application software". 111 This approach reduces the legal question of whether the subject matter constitutes an invention to a set of questions of fact of what type of improvement of what type of software counts as an improvement of hardware. ${ }^{112}$

In contrast to the UK practice, current French law officially recognises the requirement for an invention as a "true, positive and autonomous requirement" 113 which is separate from the

100 These include a discovery, scientific theory or mathematical method, aesthetic creations, a scheme, rule or method for performing a mental act, playing a game or doing business, or a program for a computer or the presentation of information.

101 Estimating Sales, at [8].

102 Ibid.

103 Odour Selection/QUEST INTERNATIONAL, T 0619/02 of 22 March 2006, EP:BA:2006:T061902.20060322, at [2.2].

104 Estimating Sales, at [5 b].

105 Odour Selection. Similarly, "where an intrinsically non-technical solution (mathematical algorithm) seeks to derive a technical character from the problem solved, the problem must be technical": Classification Method/COMPTEL, T 1784/06 of 21 September 2012, EP:BA:2012:T178406.20120921, at [2.3].

106 Programs for Computers, G 0003/08 of 12 May 2010, EP:BA:2010:G000308.20100512, at [10.7].

107 C. Birss et al., Terrell on the Law of Patents, 19th ed., (London 2020) at [2-10].

108 Biogen Inc. v Medeva plc. 38 B.M.L.R. 149, [1997] R.P.C. 1, at [41]-[42] (H.L,).

109 Aerotel Ltd. and Telco Holdings Ltd. [2006] EWCA Civ 1371, [2007] Bus. L.R. 634, at [40].

110 Gemstar-TV Guide International Inc. v Virgin Media Ltd. [2009] EWHC 3068 (Ch), [2010] R.P.C. 10, at [41][43], AT\&T Knowledge v Comptroller General of Patents [2009] EWHC 343 (Pat), [2009] Bus. L.R. D51, at [39]-[41], HTC Europe Co. Ltd. v Apple Inc. [2013] EWCA Civ 451, [2013] R.P.C. 30, at [154].

111 HTC Europe [2013] EWCA Civ 451 at [57]-[59].

112 Ibid., at [154] et seq.

113 Passa, Droit, 68. 
excluded subject matter categories. However, it seems that French courts "do not take it into consideration, at least explicitly". ${ }^{114}$ Rather, the courts follow the EPO practice. It is noteworthy that interpreting the notion of "invention" as "having a technical character" caused its semantic overlap with another patentability requirement: "[ $\mathrm{t}]$ he historic condition of industrial character may cover not only the modern requirement for industrial applicability but also the one for invention [as in the past] industrial meant to produce technical goods or results." 115

In German law, the concept of the invention has been consumed by the requirement for "technicity" which is understood as a "solution serving to solve a concrete technical problem with technical means". ${ }^{116}$ As a result, a subject matter is found to amount to an invention if it provides such a solution through technical means or if it is "characterised by a piece of knowledge that is based on technical considerations". 117

What makes some considerations technical or what types of problem can be characterised as "technical" remains unclear. The concept of the technicity (Technikbegriff) is dynamic 118 and therefore it can accommodate subject matter lying in all future branches of the traditional technical fields. ${ }^{119}$ Recently, this dynamic potential was realised when German courts accommodated data processing, storing and transmission among fields of technology. ${ }^{120}$

To summarise, the assessment of whether a subject matter amounts to an invention is concerned with its technical features or effect. The requirement is deemed fulfilled if the subject matter comprises a technical feature or relates to a technical field. As a result, the two definitional elements of (i) invention and (ii) lying in any of the technical fields (i.e. an "invention in all fields of technology"121) are merged into a single concept of the "technicity". Consequently, these approaches fail to address the possibility of a subject matter that, on the face of it, falls within a technical field or has a technical feature and which subject matter does not, however, constitute an invention - due to lack of human creative intervention.

\section{B. $\quad$ The Inventive Step Requirement}

For a grant of a European patent, an invention must be inventive in terms of involving an inventive step or activity ${ }^{122}$ as well as achieving some progress or advancement of the state of the art. ${ }^{123}$ In

114 F. Pollaud-Dulian, La propriété industrielle, 2nd ed., (Paris 2011) at [159].

115 J. Azéma and J.-C. Galloux, Droit de la propriété industrielle, 8th ed. (Paris 2017), 158-59.

116 Steuerungseinrichtung für Untersuchungsmodalitäten, Decision of 20 January 2009, X ZB 22/07 (GRUR 2009, 479) at [11].

117 Logikverifikation, Decision of 13 December 1999, X ZB 11/98 (GRUR 2000, 498) 500.

118 Ibid.

119 Nack, "Inventions", at [13].

120 In one case the required technicity was acknowledged because the claimed process run on a computer involved "typical steps of processing, storing and transmission of data via technical devices": Erfindungen mit Bezug zu eräten und Computerprogrammen, Decision of 24 February 2011, X ZR 121/09 (GRUR 2011, 610) 612. Also, in an earlier case, the underlying computer program was found inherently patentable as it fulfilled the technicity criterion by virtue of serving to processing, storing and transmission of data via a technical device. Steuerungseinrichtung, 480.

121 EPC, Article 52(1).

122 English version: Inventive step, German version: Erfinderische Tätigkeit (inventive activity) and French version: Activité inventive (inventive activity).

123 A mere disadvantageous modification of the closest prior art does not constitute an inventive step. T 2197/09 () of 20.11.2014, EP:BA:2014:T219709.20141120, at [5.4]. 
relation to human inventorship, the requirement for an inventive activity may seem to play a second fiddle to the invention requirement.

Nonetheless, this section argues that the requirement for an inventive activity reflects human inventorship in requiring a genuine intellectual activity involved in solving the underlying technical problem. The required activity is intended to be of human origin because it is referred to as "intellectual" in the EPC drafting documents and is benchmarked against a hypothetical decision-making and acts of a notional natural person, the person skilled in the art. In this respect, the person skilled in the art standard works similarly to other legal standards of notional persons, such as "reasonable person" or "average consumer".

\section{Teleological interpretation and historic reasons for a human inventive step}

Contrary to the conventional approach which is predominantly focused on inventiveness as a property of an invention, here the interpretation of the requirement begins with the literal meaning of the notion of "inventive activity" and its purpose. As a treaty of international public law, the EPC must be interpreted "in good faith in accordance with the ordinary meaning to be given to the terms of the treaty in their context and in the light of its object and purpose". ${ }^{124}$ Therefore, the terms of "inventive step" or "inventive activity" shall be given their ordinary meaning of inventive (intellectual) step or activity. Hence, the activity that is required to be involved in devising an invention under Article 52(1) and Article 56 EPC means (i) a genuine intellectual activity that is (ii) of a certain quality.

Under the heading "creative effort", the Comparative Study references a requirement that "the invention should represent a manifestation of intelligence which appreciably exceeds the normal train of thought of which any specialist in art would be capable". ${ }^{125}$ Kühnemann's report to which the EPC travaux préparatoires refer as well, formulates "the requirement of creative effort in an indirect manner so that a realisation of a subject matter that was within the reach of an average expert was excluded from patentability". ${ }^{126}$ Additionally, a German delegate to the Patents Working Party expressed the view that "under German law, the concept of Erfindungshöhe [inventive level] did not necessarily involve creative effort (flash of genius) on the part of the inventor. It was enough if he broke new ground and applied some intellectual activity." 127

There is an observable tension inherent in these accounts. On one hand, an involvement of inventor's genuine intellectual activity in the process of devising an invention is both presupposed and required. Requiring a genuine intellectual activity is also aligned with the purpose of patent systems as laid out in justificatory theories (section IV(D). below). On the other hand, when it comes to the inventive quality of the activity and how to prove it, there is a reluctance to define it in positive terms.

As a result, Article 56 EPC provides for a legal presumption of inventive activity: "[a]n invention shall be considered as involving an inventive step if, having regard to the state of the art, it is not obvious to a person skilled in the art." Hence, inventiveness is measured according to an objective standard of an average expert and a hypothetical of what would have been within their

124 Article 31 of the Vienna Convention on the Law of Treaties 1969.

125 R. Gajac, "Comparative Study", 16, copy on file with author.

126 Kühnemann Report on Technological Progress and Creative Effort as Patentability Criteria. EXP/BRev (60) 5 available at https://rm.coe.int/090000168072965b (last accessed 29 March 2021).

127 Proceedings of the $1^{\text {st }}$ meeting of the Patents Working Party held at Brussels from 17 to 28 April 1961, Document IV/2767/61-E, 18, available at https://www.epo.org/law-practice/legal-texts/epc/archive/epc1973/traveaux.html (last accessed 29 March 2021). 
reach. In effect, to make an inventive invention, an inventor is required to do what an average expert would not have done.

\section{Application of the inventive step requirement}

Where an invention consists of both technical and non-technical features, the inventive step is assessed only in respect of those features that contribute to the solution of the technical problem by providing a technical effect ${ }^{128}$ (or a further technical effect in case of computer-implemented methods). Hence, the necessary intellectual activity ${ }^{129}$ should be involved directly in solving a technical problem and thus be reflected in those features that contribute to the solution. ${ }^{130}$

However, in practice, the EPO does not examine whether an intellectual activity was actually involved in solving the underlying problem. Rather, the EPO deals exclusively with the inventiveness (or non-obviousness) standard. Whether the standard is achieved is examined from the position and capabilities of a person skilled in the art ("PSA"). The PSA is a notional expert (or a team of experts) in the technical field of the invention ${ }^{131}$ who has common general knowledge, has read all publicly available documents, knows publicly available uses of the technology, understands all languages ${ }^{132}$, and possesses the necessary equipment and technical tools which vary according to the technical field. This person is conservative ${ }^{133}$ and unimaginative and therefore they would miss every step that goes beyond ordinary good practice and routine.

To determine whether an invention is non-obvious, the EPO uses a so-called problem-andsolution test. The test comprises of the following steps: "determining the 'closest prior art', defining the 'objective technical problem' to be solved, and assessing whether, or not the claimed invention, starting from the closest prior art and the objective technical problem, would have been obvious to the skilled person". ${ }^{134}$

The UK non-obviousness test, the "Windsurfing/Pozzoli test", is a kind of a problem-andsolution test which in its fourth stage (closes the circle as it) asks whether overcoming the differences between the prior art and the invention is obvious or requires any degree of invention, i.e. an inventive activity. ${ }^{135}$ The UK courts approach obviousness as a multi-factorial assessment, ${ }^{136}$ a kind of jury question, whereby finding obviousness depends on concrete circumstances of the case. ${ }^{137}$

128 Two Identities/COMVIK, T 0641/00 of 26 September 2002, EP:BA:2002:T064100.20020926, at [6]. Estimating Sales, at [5 e)].

129 As acknowledged elsewhere, "while the exercise of (mental) labour and effort is a necessary condition for an invention to be non-obvious, it is not a sufficient condition": Bently et al., Intellectual Property Law, 591.

130 Naturally, there are many ways how a technical problem can be solved. Some people may start from a predefined technical problem and devise a solution to it, e.g. the example of identifying halicin. This will be typical for solutions offered by AI-driven systems. Others may start with finding an object and then devising its purpose or implementation to solve technical problems. See the section on "Origin of an invention" in the EPO, Guidelines, Part G, Chapter VII, at [9].

131 P. Johnson, "EPC 2000, Art 56" in R.J. Hacon and J. Pagenberg (eds), Concise European Patent Law, 2nd ed. (Alphen an den Rijn 2008) 52.

132 Combustion Engine, T 0426/88 of 9 November 1990, EP:BA:1990:T042688.19901109, at [6.4].

133 Genentech/Expression in Yeast T 445/91 of 20 June 1994, EP:BA:1994:T045591.19940620, at [5.1.3.3].

134 EPO, Guidelines for Examination (Munich 2021), Part G, Chapter VII, at [5].

135 Pozzoli SPA v BDMO SA, [2007] EWCA Civ 588, [2007] Bus LR D117, at [23].

136 Actavis UK Ltd. v Novartis AG [2010] EWCA Civ 82, [2010] F.S.R. 18, at [41].

137 Generics (UK) Ltd. v H Lundbeck A/S [2007] EWHC 1040 (Pat), [2007] R.P.C. 32 at [72], in this part confirmed by the Court of Appeal in H. Lundbeck A/S v Generics (UK) [2008] EWCA Civ 311, [2008] R.P.C. 437, at [24] (C.A.). 
In Actavis v ICOS the Supreme Court stressed that the problem-and-solution tests should not be applied mechanistically. ${ }^{138}$ This case cautions against the reduction of the assessment of an inventive step to a mere test for non-obviousness as manifested in the invention. An invention can (wrongly) be found inventive only because in its concrete form (e.g. $5 \mathrm{mg}$ dose in Actavis v ICOS) it would have been non-obvious and surprising to the PSA at the beginning of the process of its devising. However, it would be wrong to infer involvement of an inventive activity from the nonobviousness of the invention because the non-obvious air of the invention does not make routine, non-inventive steps (which would have led to its devising) inventive. As reiterated by the Supreme Court, the steps or the activities which would have been undertaken by a PSA in the process of devising the invention are decisive.

German courts, too, apply a problem-and-solution test ${ }^{139}$ within which they address the following questions: (a) Which steps would the PSA have had to undertake so that they achieved the solution of the patent in question? (b) Would they have had any instigations or considerations prompting them to set the direction towards the invention? (c) What are the reasons for or against the fact that the PSA would have arrived at the solution proposed in the patent on the basis of such considerations? ${ }^{140}$ The focus is strictly on the comparison of the actual outcome and a hypothetical outcome of a hypothetical process of thinking and acting which would have been performed by a PSA. ${ }^{141}$

The approach of French courts closely follows the one of the EPO as well. ${ }^{142}$ In brief, according to the French Supreme Court, it is sufficient to succinctly conclude that "the state of the art did not suggest the invention" 143 and, as a consequence, trigger the legal presumption of inventive activity.

In sum, the approaches to the application of the inventive step requirement have developed to a mere comparison of the claimed invention with the prior art. The authorities then may easily lose sight of the literal meaning and purpose of the requirement for an inventive step and omit to ask whether a genuine intellectual activity was involved in the process of invention and whether this activity was of a certain quality which is to be measured by PSA's hypothetical steps.

3. The Actual Inventive Activity and Typology of Inventive Activities

Despite the proclaimed disregard for the way the inventor made their invention or inventor's subjective assessment of their efforts, ${ }^{144}$ the UK courts consider so-called "secondary evidence" relating to the contemporaneous events, reactions to the invention, the realities surrounding making the particular invention and actual ways of approaching the particular technical problem undertaken at the time of the invention. ${ }^{145}$ Telling the actual story of an inventor devising the invention can be favourable to the patentee. ${ }^{146}$

138 Actavis v ICOS [2019] UKSC 15, at [62] and [67]-[72].

139 A. Keukenschrijver et al., Patentgesetz: Kommentar, 8th ed. (Berlin 2016), §4, at [25].

140 C. D. Asendorf and C. Schmidt, "Erfindung auf Grund erfinderischer Tätigkeit" in G. Benkard, Patentgesetz (Munich 2015), §4, at [21].

141 C. Ann, "Erfinderische Leistung" in R. Kraßer and C. Ann (eds.), Patentrecht, 8th ed. (Munich 2016) §18, at [11].

142 Passa, Droit, at [190].

143 Cour de cassation, Decision of 8 October 2002, INPI database.

144 Nichia Corporation v. Argos [2007] EWCA Civ 741, [2007] Bus. L.R. 1753, at [13].

145 A list of secondary factors was provided by Justice Laddie in Haberman v Jackel Int. Ltd. [1999] F.S.R. 683, 699-701.

146 Actavis v ICOS [2019] UKSC 15, at [71]. Positec Power Tools (Europe) Ltd. v Husqvarna AB Chancery Division [2016] EWHC 1061 (Pat), [2016] Bus. L.R. 714, at [8]. 
Moreover, the German and French application practice yields a typology of inventive activities. The activities of overcoming technical obstacles, formulating a novel technical problem and breaking new ground, ${ }^{147}$ answering a series of objectively difficult questions, ${ }^{148}$ reversing a bias, misleading belief or technical stereotype, ${ }^{149}$ surprising a PSA,${ }^{150}$ making a selection from among a great number of possible solutions or combining at least three documents of prior art ${ }^{151}$ are all considered inventive. Thereby, the jurisprudence indicates what kind of activity may constitute the necessary intellectual activity to devise an invention.

\section{Human Inventorship as Reflected in the Statutory Patentability Requirements}

It is necessary to acknowledge that the requirements for an invention and inventive activity do not offer a complete picture of human inventorship even if read in the light of the underlying factual assumptions and the purpose of these requirements. Yet, they render some reflection of human inventorship: a subject matter must constitute a creation, i.e. a result of a human intervention which intervention directly and causally determines the relevant elements of the subject matter to meet the requirement for an invention. To meet the requirement for an inventive activity, a subject matter must constitute a result of a genuine intellectual activity expended on solving the technical problem in a manner that makes the invention inaccessible to an average expert.

If European patent law is treated as a coherent body of norms, the national rules on inventorship for entitlement purposes (which define the inventor as a person who devises, makes, or originates an invention) could help to sharpen the contours of the implicit requirement for (general) human inventorship. Bringing these national rules on individual inventorship and the reflection of human inventorship in the statutory patentability criteria together, human inventorship requires an invention to be devised through a human creative intervention and intellectual activity of inventive quality.

A subject matter that is not a result of the required human creative intervention and human inventive activity is not merely excluded because there is no "inventor," but also because there is neither an "invention" nor subject matter that involves an "inventive step." Such subject matter cannot be readily accommodated by the EPC system without compromising the system's theoretical basis, foundational factual assumptions and rules on entitlement and designation of the inventor.

\section{Human Inventorship as Reflected in Justificatory Theories}

On a more abstract level, human inventorship and human creative activity are the cornerstones of many patent justificatory theories which accompany patent laws from their early days until today. Human intellectual creative effort, conception of an idea and mental labour are nowadays associated with copyright rather than with patents. Despite this stereotype, in the nineteenth century, the language of creativity was used in "all areas of law which granted property rights in

147 Alcan/Aluminium Alloys, T 465/92 of 14 October 1994, EP:BA:1994:T046592.19941014, at [9.5].

148 Keukenschrijver et al., Patentgesetz, \$4, at [116].

149 Ibid., at [48]-[49]. Cour de cassation, Decision of 19 December 2000, INPI database.

150 Disiloxan, Decision of 27 February 1969, X ZB 11/68, 7.

151 All in The National Industrial Property Institute, "La délivrance des brevets et des certificats d'utilité" available at https://www.inpi.fr/sites/default/files/directives_brevets_version_octobre_2019_2.pdf (last accessed 31 January 2021), 96. 
mental labour" 152 , including patent law, and "the model of creativity employed by the law was not limited to literary property nor was it restricted to the late eighteenth century". ${ }^{153}$

For Adam Smith, Jeremy Bentham and John Stuart Mill, patents were just compensation and reward for a person's mental labour and experimental endeavours. ${ }^{154}$ While these "reward-bymonopoly" theories were based on merit and fairness reasons, ${ }^{155}$ the idea of patents as rewards and thus incentives for human creative activity forms part of more contemporary narratives as well.

For instance, as put by the economist Fritz Machlup in the mid-twentieth century, "the profit expectations connected with the hope for a patent monopoly may induce inventive talents to exert their efforts ...". ${ }^{156} \mathrm{He}$ further acknowledges that even after the ways of organising research and innovation in technology have changed over time, the ultimate task - to induce inventive talents to exert their effort-remains unchanged. ${ }^{157}$ The common justificatory theme of the reward and incentives theories is the involvement of human intellectual and creative activity in a process that results in an inventive contribution to the art.

There are other influential justificatory theories that are not centred on human inventorship. Chief among them is "exchange-for-secrets" theory which is oriented at disclosing inventions in a sufficient (or enabling) manner in contrast to keeping them in secrecy. In the UK, the requirement of sufficient disclosure emerged in case law in the final decades of the eighteenth century. ${ }^{158}$ In this connection, a theory of social contract between an inventor and the public developed whereby the justification for granting patents became the sufficiency of disclosure of the invention. Yet, even after the social contract model established itself as the dominant justification in the UK, inventors' labours and heroic stories of invention were reasons for special recognition through rewards granted by the Parliament. ${ }^{159}$

What is more, the "exchange-for-secrets" theory has never operated self-sufficiently. It rather stands on the shoulders of the property, reward, and incentive theories as it neither relies on disclosing subject matter that have not been devised nor justifies property rights where the legitimising relationship between the subject matter and its inventor is missing. ${ }^{160}$

Another set of justificatory reasons for the patent system is offered by Kitch's prospect theory. This asserts that the patent system promotes the efficient allocation of opportunities (prospects). ${ }^{161}$ However, as Kitch himself acknowledges, his prospect theory is only complementary to rewards theory which is founded on human inventorship. ${ }^{162}$

Hence, the raison d'être of patents can be formulated as to incentivise human beings (possibly through intermediaries) to employ their brainpower, talents, and creativity in efforts to devise a contribution to the state of the art and, if successful, disclose it in a sufficient manner. It

152 Sherman and Bently, The Making, 44.

153 Ibid.

154 M. Fisher, "Classical Economics and Philosophy of the Patent System" (2005) I.P.Q. 1, 8-10.

155 Ibid.

156 F. Machlup, An Economic Review of the Patent System, Committee Print (Washington 1958), $23-24$.

157 Ibid., 36.

158 L. Bently, "Patents and Trade Secrets in England: The Case of Newbery v. James (1817)" in R.C. Dreyfuss and J.C. Ginsburg (eds.) Intellectual Property at the Edge: The Contested Contours of IP (Cambridge 2014) 31213.

159 R. Burrell and C. Kelly, "Parliamentary Rewards and the Revolution of the Patent System" [2015] C.L.J. 423, 439-41.

160 If the exchange-for-secret theory could stand alone, then, for instance, the designation of an individualised human inventor or the dependency of entitlement on the inventor would not have to be required.

161 E. Kitch, "The Nature and Function of the Patent System" (1977) 20 J. Law Econ. 265.

162 Ibid., 266. 
follows that any contributions to the state of the art whose production did not involve human inventorship in the above sense ought to lie outside the scope of patent protection.

\section{TEST FOR HUMAN INVENTORSHIP}

Since an individualised human inventor who devised an invention is factually presupposed, the EPC system has not hitherto developed specific means to verify or test whether an invention the subject of a patent application indeed has a human inventor. The human inventorship aspects are almost entirely overlooked in the application of the requirements for an invention and inventive activity. Before AI-driven systems replace human inventors in performing narrowly defined tasks of solving specific technical problems and authorities encounter technical solutions with no human inventors, these shortcomings may be regarded as mere idiosyncrasies of the system. Yet, given the current advancements in AI and the deployment of neural networks in the production of inventions, the factual assumptions about human inventorship become problematic.

Therefore, this article proposes a reform that builds on the implicit requirement for human inventorship. Foremost, the requirements for an invention and inventive step should be interpreted in a way that takes their human inventorship aspects into account, i.e. whether the subject matter owes its existence to a human creative intervention and intellectual activity of inventive quality. For this purpose, patent applicants should be required to disclose the role of an AI-driven system, ${ }^{163}$ if any, in devising the subject matter in a manner enabling to conduct an adequate patentability assessment.

Such a disclosure could be part of the description of the technical problem and solution according to Rule 42. ${ }^{164}$ The applicant would be obliged to disclose if, and to what extent, an AIdriven system was used and describe the steps in the process that were undertaken by it. Whenever an applicant fails to explain the steps undertaken by an AI-driven system and their significance, the EPO should refuse the application under Article 90 EPC for not complying with the formal requirements of patentability.

The disclosure should supply enough information to assess, on a case-by-case basis, whether the activities conducted by human beings in the process of devising the subject matter possessed the required creative and intellectual inventive quality in relation to the technical features of the subject matter. For instance, if the invention is found non-obvious, it should also be ascertained whether the non-obviousness is not due to the steps undertaken by the AI-driven system (which may be superior to the state-of-the-art AI-driven systems).

In practical terms, such a reform could be easily achieved because it is a mere extension of the existing description of the technical problem and solution under Rule 42 with a view to equipping examiners with more relevant information. ${ }^{165}$ The reform is not in conflict with the EPC

163 An AI-driven system could be defined as a system that can perform tasks such as decision-making, problemsolving, etc which normally require human intellectual activity. This proposal stems from definitions of AI offered in Russell and Norvig, Artificial intelligence, 1-2.

164 Implementing Regs. See also EPO, Guidelines, Part F, Chapter II, at [4].

165 Similar arguments were made by Sherman in relation to disclosure of biological resources and indigenous knowledge with a view to learning their role in scientific and technical developments: B. Sherman, "Regulating Access and Use of Genetic Resources: Intellectual Property Law and Biodiscovery" (2003) 25 E.I.P.R. 7, 30708 . 
Contracting States' commitments in the realm of patent law because it does not introduce any new patentability condition, nor impedes the grant of patents procedurally. ${ }^{166}$

To ensure a wider scrutiny of involvement of human inventorship, competitors and the public in general should be able to challenge the accuracy of the disclosure before the EPO or national courts, e.g. via revocation under Article 138(1)(a) EPC on the ground that the subject matter is not patentable. ${ }^{167}$ At the end of the day, this would enhance transparency regarding the role of AI in the production of inventions and enable recalibration of examination practices accordingly.

\section{CONCLUSION}

If modern patent law is to cope with the ever wider and more significant employment of AI-driven systems in devising novel technical solutions, it is desirable to remedy the shortcomings in examination and adjudication approaches. At the heart of the problem is a failure of the current approaches to appreciate the central role of human inventorship not only in determining the entitlement to a patent but also in the patentability of a subject matter. To establish the presence of human inventorship with confidence, applicants should be obliged to disclose the necessary information. Only then it will be possible to ensure that the patent protection is restricted to the true inventors for their inventions.

166 By analogy N.P. de Carvalho, "Requiring Disclosure of the Origin of Genetic resources and Prior Informed Consent in Patent Applications Without Infringing the TRIPS Agreement: The Problem and the Solution" (2000) WASH. U.J.L. \& POL'Y 371, 372 and 382.

167 If this were accepted, a further thought should be given as to where to place the burden of proof. 